\title{
Heritage of the alash intellectuals on the problems of education of Kazakh children
}

DOI: 10.31551/2410-2725-2018-4-3-427-437

\section{Sadvokasova Zakish Tulehanovna}

Doctor of Historical Sciences, Professor, Chief Researcher at the Institute of History and Ethnology named after Ch.Ch. Valikhanov of the Science Committee of the Ministry of Education and Science of the Republic of Kazakhstan. 050010 Almaty, Republic of Kazakhstan, Shevchenko street 28. E-mail: tungatar_k@mail.ru

\begin{abstract}
The article deals with the problems of education of Kazakh children. The state of education in Kazakhstan at the turn of the 19th and 20th centuries is shown on the basis of the study and analysis of the heritage of the Alash intelligentsia. Criticizing the policy of the autocracy in the sphere of education, advanced members of the Kazakh society observed the backwardness of the school system, oppression of attempts to introduce new methods of instruction, russification. Representatives of «Alash» in the initial period of Soviet construction, hoped for improvement in the field of education. However, along with the spread of general literacy, many difficulties arose to achieve the goal that the Alash intelligentsia tried to overcome.

Keywords: enlightenment; heritage; the Alash intelligentsia; schools; training; literacy.

\section{Қазақ балаларын тәрбиелеу мәселесіндегі Алаш интеллигенциясының мұрасы (қазақ мемлекеттілігінің контексінде)}

\section{Садвокасова Закиш Тулехановна}

тарих ғылымдарының докторы, профессор, ҚР БҒМ ҒК Ш.Уәлиханов атындағы тарих және этнология Институтының бас ғылыми қызметкері. 050010. Қазақстан Республикасы, Алматы қ, Шевченко к, 28. E-mail: tungatar_k@mail.ru

Аңдатпа. Бұл мақалада қазақстандық балаларды тәрбиелеу мәселелері талқыланады. Алаш интеллигенциясының мұрасын зерделеу және талдау негізінде, Қазақстандағы 19-20 ғасырлардағы білім беру деңгейі көрсетіледі. Білім беру саласындағы автократия саясатын сынға ала отырып, қазақстандық қоғамның озық мүшелері оқытудың жаңа әдістерін енгізуге әрекеттеніп, мектеп жүйесінің артта қалуын, орыстандыруды көрді. Кеңес құрылысының алғашқы кезеңінде Алаш өкілдері білім беруді жақсартуды ойлады. Алайда, әмбебап сауаттылықтың таратумен қатар Алаш зиялы қауымының өкілдері мақсаттарға жету үшін көптеген қиындықтарды жеңуге тырысқан болатын.

Түйін сөздер: ағартушылық; мұра; алаш зиялылары; мектептер; білім беру; білімділік.

\section{Наследие алашской интеллигенции по проблемам просвещения казахских детей (в контексте казахской государственности)}

\section{Садвокасова Закиш Тулехановна}

доктор исторических наук, профессор, главный научный сотрудник Института истории и этнологии имени Ч.Валиханова Комитета науки Министерства образования и науки Республики Казахстан. 050010. Республика Казахстан, г. Алматы, ул. Шевченко, 28. E-mail: tungatar_k@mail.ru

\begin{abstract}
Абстракт. В статье рассматриваются проблемы просвещения казахских детей. На основе изучения и анализа наследия алашской интеллигенции показано состояние образования в Казахстане на стыке 19-20 веков. Критикуя политику самодержавия в сфрере образования, передовые члены казахского общества видели отсталость системы школьного образования, притеснение попыток введения новых методов обучения, русификацию. В начальный период советского строительства представители «Алаш» надеялись на улучшение в деле просвещения. Однако, наряду с распространением всеобщей грамотности, возникало немало трудностей для достижения цели, которые старалась преодолеть алашская интеллигенция.
\end{abstract}

Ключевые слова: просвещение; наследие; алашская интеллигенция; школы; обучение; грамотность. 


\section{УДК 94(574)19/20}

\section{Наследие алашской интеллигенции по проблемам просвещения казахских детей (в контексте казахской государственности) ${ }^{1}$}

\section{T. Садвокасова}

Изучение деятельности участников алашского движения активизировалось во времена перестройки и особенно актуализировалось в период независимости. Это связано с возможностью объективного исследования трудов и деятельности членов партии «Алаш», без давления коммунистической идеологии. Отличительной чертой алашординцев является их упорное стремление к восстановлению казахского государства. Преследование за свободолюбивые идеи их не останавливало, о чем свидетельствуют новые выявленные документальные материалы. Многие были уничтожены и их имена ассоциировались с такими понятиями как «враг народа», «буржуазный националист», «наймиты буржуазии» и т.д. На нынешнем этапе большая значимость имеет программа «Духовное возрождение», одной из задач которой является восстановление национального кода. Именно алашординцы боролись за его сохранение.

Передовые члены казахского общества в основном были выпускниками высших и средних учебных заведений. Обучаясь в среде образованных людей, проживая в городах, совершенно непохожих на родное окружение, думали о путях и необходимости перемен, связывая их с просвещением. Молодая высокообразованная молодежь по сравнению с другими представителями высших слоев видела возможные негативные последствия безграмотности своего народа, поэтому, в выступлениях, публикациях часто поднимали проблему просвещения казахских детей.

Наследие алашской интеллигенции по вопросам просвещения в Казахстане до настоящего времени мало изучено. В первые годы советской власти проблематикой научных исследований выступали социально-экономические отношения, земельные вопросы, противоборство классов, деятельность российской социал-демократической рабочей партии, ее групп в регионах и т.д. Позже на повестку дня встают задачи по решению проблем борьбы с неграмотностью, где главная роль отводилась коммунистам. Лидеры алашского движения не только искали пути к просвещению казахов, но и сами принимали активное участие в ликвидации безграмотности. Политические репрессии 193738 годов и последовавшие меры по вытравлению из памяти казахского народа имен алашординцев надолго оставили историю Казахстана без этих исторических личностей. Если шло упоминание кого-нибудь из них, то лишь в контексте деятельности буржуазных националистов против советской власти или «врагов» народа. Первых противников можно было «перевоспитать», «переубедить», "склонить» на сторону большевиков, вторые же не могли иметь право на жизнь в новом обществе, где между двумя дружественными классами: рабочими и колхозниками не могло быть разногласий. Они подлежали уничтожению.

Историография по проблеме просвещения казахских детей представлена рядом научных трудов, хронологические рамки которых включают царский и

\footnotetext{
${ }^{1}$ Исследование выполнено при фринансовой поддержке Комитета науки Министерства образования и науки Республики Казахстан в рамках ПЦФ проекта BR05236705 «Алаш в истории государственности Казахстана: идеи, судьбы, наследие (в контексте духовной модернизации общества)».
} 
советский периоды. В научных трудах Т. Тажибаева, К. Бержанова, Н. Сабитова, совместной работе А.И. Сембаева, Г.М. Храпченкова (Тажибаев 1962: 507; Тажибаев 1965: 164; Бержанов 1965: 344; Сабитов 1950: 44; Сембаев, Храпченков 1972: 164) освещается политика самодержавия в области образования казахских детей. Наряду с положительными переменами в школьном обучении: введение программ, деление на классы, определение времени каникул и т.д., они нередко указывают на негативные стороны фрункционирования русскоказахских, туземных школ, заключающиеся в политике русификации. Советские историки, обращаясь к лозунгу о равноправии наций, приводили примеры насильственной обрусительной политики в учебных заведениях национальных окраин в царский период. Так, об опыте работы казахских школ при укреплениях, не оправдавших надежд администрации, Т. Тажибаев, приводит недовольные высказывания инспектора народных училищ Туркестанского края Н.П. Остроумова: «Из этих школ не вышло ни одного обруселого, ни образованного киргиза, так как обе школы обладали слишком мелкими образовательными средствами и еще потому, что учителями в этих школах были инородцы, едва ли проникнутые идеей обрусения» (Тажибаев 1962: 25).

Течение джадидизма, связанное с появлением новометодных школ, советские исследователи в основном рассматривали как взращивание в них будущих представителей национальной буржуазии, что шло вразрез с классовым подходом и изучать деятельность таких школ не следует.

О критике казахской интеллигенцией политики царизма в отношении инородческих учебных заведений старались замалчивать. Хотя и они видели недостатки в системе образования и в выступлениях открыто выражали протест против образовательной политики. Допускалось освещение негативных последствий колониальной политики в области просвещения советскими учеными для сравнения положения национальных школ в годы царизма и нового строя. Труды исследователей из капиталистических стран были отнесены к работам, фальсифицирующие советский строй и деятельность коммунистической партии.

После распада советской страны стали появляться труды зарубежных исследователей, анализирующих положение в сфере образования в союзных республиках. Работе школ и советских учителей во времена переустройства общества, введения всеобщего обучения и захлестнувшую страну политические репрессии посвятил свое научное исследование Томас Юнг под названием: «Учителя эпохи сталинизма: власть, политика и жизнь школы 1930-х годов» (Юнг 2011: 359). На материалах из разных регионов советской страны он описывает повседневную жизнь учителей начальной и средней школы. Автор книги приводит ряд примеров, свидетельствующих о политизации школы. Слежка за учителями велась постоянно. Так, исследователь пишет о том, что одного обвинили в «антисоветских методах», другому повесили ярлык «аполитичного и антисоветского элемента», третьего упрекнули за то, что на уроке биологии об эволюции она не коснулась антирелигиозной и интернационалистской тематики. Подверглась критике учительница за то, что «на уроке о Средневековье она не рассказала, как бурно развивается Средняя Азия», а директору школы в Татарии сделали выговор, потому что на уроках ботаники не упоминался ни Сталин, ни партия» (Юнг 2011: 242). То есть и в советский период в школах доминировала политическая функция. Подобное положение было замечено одним из представителей казахской интеллигенции А. Букейхановым в учреждениях просвещения на территории Казахстана в годы царизма.

Монографрии, очерки, авторефераты, изданные в годы независимости, по различным вопросам, в том числе по тематике просвещения казахских детей 
уже включали имена деятелей «Алаш», вследствие того, что большинство из них были реабилитированы в годы перестройки. Издаются на казахском языке и переводятся на русский труды алашской интеллигенции (Байтурсунов 1989: 320; Дулатов 1997: 205; Букейханов 1993: 478; Тынышпаев 2009: 279; Сейфуллин 1987: 399). Выпускаются многотомники трудов видных деятелей «Алаш» в дополнение предыдущих выпусков.

Казахстанские историки исследуют жизнь и деятельность алашских лидеров и активистов на поприще образования, науки и культуры: Ахмета Байтурсунова, Алимхана Ермекова, Мыржакыпа Дулатова, Турара Рыскулова, Жакыпа Акпаева и других (Байтелесова1998: 78; Кыдыралина 2012: 320; Галиев 2011: 528; Ахметов 2008: 204; Кул-Мухаммед 1995: 240).

Вносят свою лепту в дело по возвращению имен алашординцев историки из регионов Казахстана. Так, большая работа по сбору материалов о знаменитых земляках из северного Казахстана, принимавших участие в жизни республики в первые годы установления советской власти и до их фризического уничтожения, проводится краеведом Кайроллой Мукановым. Его книги посвящены таким личностям как: Жумагали Тлеулин, Хамза Ибрагимов, Рамазанов Аблай. (Муканов 2005: 216; Муканов 2014: 294). Собирая по крупицам материал об их жизни и деятельности в архивах области и республики, беседуя с родственниками, К. Муканову удалось описать насыщенную событиями, биографию одного из участников алашского движения.

Российские ученые также объектом своих научных исследований выбирают деятельность представителей алашской интеллигенции. Оренбург был первой столицей советского Казахстана. Свой вклад в развитие города в 20-е годы внесли образованные казахи. Значение этого города в жизни А.Байтурсынова показано в книге Т.И.Тугай «Оренбургский путь Ахмета Байтурсунова» (Тугай 2017: 188). Особо хотелось бы подчеркнуть то, что автор в конце 2017 года провел презентацию книги в Институте истории и археологии имени Ч. Валиханова в Алматы. В «Оренбургском пути...» получили отражение важные этапы биографии выдающегося человека: учеба, начало педагогической деятельности, работа в народном комиссариате просвещения Казахской автономной Советской Социалистической республики.

Проводятся научные конференции, посвященные «Алаш-Орде» и его деятелям, желавшим видеть свою родную землю свободной и независимой (Материалы конфреренции 2017). Исследователи дают высокую оценку их вкладу в развитие страны и ее государственности. Особо подчеркивается их значимость в воспитании патриотизма и гордости за свой народ у подрастающего поколения.

Состояние просвещения изучалось казахской интеллигенцией задолго до образования партии «Алаш». Поэтому в трудах, где рассматриваются проблемы образования, анализируются причины малограмотности, пути преодоления возникающих препятствий к знаниям, нашли отражение в данной статье.

Изучал состояние просвещения в Казахстане в начале $\mathrm{XX}$ века выпускник Санкт-Петербургского Императорского Лесного института А. Букейханов. Используя сведения экспедиции Щербины, он приводит цифровые данные о наличии аульных школ в областях Казахстана по губернским обзорам 1905 года: в Семиреченской - 257 учащихся обучалось в 13 школах, Акмолинской соответственно 301 в 14, и наибольшее количество в Тургайской -1672 учащихся в 94 аульных школах (Букейханов 2007: 36). Последние данные подвергаются сомнению и, на наш взгляд, завышены. При несложных арифметических действиях получается, что в одной Тургайской области школ и учащихся было почти в 2 раза больше, чем в трех областях вместе взятых. Тем не менее, приве- 
денное количество школ и учащихся показывает, что система начального образования среди казахов стояла на низком уровне. При такой сложной ситуации, коренное население избегало аульные школы в силу того, что они открывались русской колониальной администрацией, препятствовавшей использованию арабских букв и изучения ислама. В просьбе казахов к местным чиновникам разрешить преподавать "учение ислама и грамоту по-киргизски» (Букейханов 2007: 34) было отказано, что послужило толчком открытия незарегистрированных учебных заведений. К ним можно присоединить новометодные школы, открывавшиеся в конце XIX века на территории Казахстана. Они использовали систему, разработанную крымским татарином Исмаилбеком Гаспринским, не получившую поддержки со стороны официальных органов управления и вынужденных скрывать свою деятельность.

К слову, в начале против этих школ выступали и муллы, увидевшие в них серьезных конкурентов. С течением времени прогрессивные служители ислама включились за пропаганду обучения по новой системе и сами открывали казахские школы на собственные деньги. К числу их можно причислить ходжу Турусбека Маманова, «который считался среди казахов мудрейшим человеком, будучи еще жив, ничего не жалел для народа» (Кул-Мухаммед 1995: 25). В 1899 году Калкабай Маманов и его сыновья Турусбек, Сейтбаттал, Есенкул открыли казахскую школу в Капале, где изучали и светские дисциплины. Нелегко было убедить старейшин рода в необходимости получения детьми разносторонних знаний. Они старались донести идею и пользу новых подходов в обучении: «Несмотря на религиозные, национальные, языковые различия, мы живем с татарами, русскими и другими народами под общим небом, в одном саду божьем, в котором переплетены корни, шумят кроны деревьев, богатые листвой и цветущие, взаимно опыляя друг друга» (Калиулы 1999: 53). Замыслы передовых мусульманских служителей о приоритетности светского образования восторжествовала. В школе обучали математике, фризике, географии, природоведению, истории, родному языку, арабскому и русскому языкам, изучали Коран. Позже на страницах популярной газеты «Казах», редакторами которой были представители казахской интеллигенции, журнала «Айкап» Мамановы ежегодно давали объявления о приглашении работать в школе опытных учителей. Так, на такой призыв откликнулись и дали согласие: Т. Мусагалиев, окончивший Каирский университет, правовед, владеющий восемью языками, видный демократ-просветитель, М. Малдыбаев - известный писатель, публицист, демократ-просветитель, ученый и другие образованные люди того времени (Калиулы 1999: 57).

В учебных заведениях на территории Казахстана, находящихся под контролем колониальной администрации, по наблюдениям А. Букейханова преобладала политическая ффункция школы над образовательной, что явилось причиной их непопулярности. В своей работе «Исторические судьбы Киргизского края и культурные его успехи» он отмечает, что в этих школах больше заботились о том, «чтобы дать им определенное идейное направление» (Букейханов 1989: 63). Такая постановка школьного дела привела к низкому образовательному уровню учащихся.

События 1917 года в Российской империи, а именно перемены, связанные с фревральской и октябрьской революциями, отразились на жизни казахского общества. За небольшой промежуток времени между двумя крупными российскими политическими переворотами в Казахстане проводились различные собрания, съезды, заседания, на повестке дня которых стояли самые злободневные вопросы. Не осталась без внимания проблема просвещения. В газете «Ка- 
зах» помещено сообщение о состоявшемся съезде учителей в Кызылжарском уезде с 1 по 8 мая. Автор корреспонденции отмечает, что наряду с другими проблемами, обсуждался вопрос о деятельности туземных школ. Первым пунктом принятого постановления было то, что «обучение должно проходить только на родном языке» (Решение учительского 1998: 389). Далее, в решении съезда отмечалось: «русский язык в течение трех лет не вводить; совместное обучение мальчиков и девочек; школьный курс в течение 6 лет; права туземных учителей уравнять с русскими» (Решение учительского 1998: 389). Примечательно, что один из пунктов гласил об обязательном введении курса русского языка. Предполагается, что после истечения трехгодичного срока, запрет на изучение русского языка снимался. Решение принималось без вмешательства русской администрации.

Накануне октябрьского переворота с 21 по 26 июля прошел всеказахский съезд, разработавший проект программы партии «Алаш». В ней наряду с вопросами государственности, управления, основных прав гражданина и т.д., было уделено внимание народному просвещению, где указывалось, что обучение должно быть «всеобщее, бесплатное на родном языке. Открывать в Киргизии на киргизском языке средние и высшие учебные заведения, область просвещения должна быть автономной; обучение по выбору. Открывать библиотеки, читальни» (Койгельдиев 2007: 125). Решение злободневных вопросов, связанных с просвещением не ограничивались рамками начальной школы. Отсутствие высших учебных заведений на территории с населением более 4 млн. человек, выдвинуло задачу подготовки на местах высококвалифицированных кадров, то есть создание сети вузов и техникумов.

Свержение Временного правительства в 1917 году, разработка программ по равноправию народов, развитию национальной культуры, родного языка и т.д., было встречено с большой надеждой алашской интеллигенцией на создание казахской государственности. Однако, дальнейшие события показали, что еще нужно пройти долгий и трудный путь к восстановлению независимости. С первых дней советской власти лидеры «Алаш» находились на линии противостояния с большевиками, так как основные вопросы самостоятельного развития казахов не получили должного решения и поддержки. Впоследствии они вынуждены были принять идеологию большевиков и вместе с тем пытались осуществить свои идеи по дальнейшему развитию народа. Большое значение придавалось просвещению детей.

После того, как представители «Алаш» пошли на компромисс с большевиками, они старались решить многие проблемы казахского народа. В Оренбурге в 1920 году А.Байтурсунов докладывал Совнаркому КАССР о состоянии народного просвещения, подчеркивая, что в указанной области, как и других сфрерах жизнедеятельности людей, многое зависит от времени, места и обстоятельств. Учитывая «ненормальность времени, не благоустроенность места, необычность обстоятельств создает сумму условий, неблагоприятных для правильного планомерного ведения дела в области просвещения» (Койгельдиев 2007: 87). Действительно, переход от одной системы к другой вызвал немало трудностей. Резкие перемены отразились на положении коренных жителей. Продолжающая политика перевода кочевников к оседлому образу жизни, неспокойное время противостояния между потерявшими власть и захватившими ее в свои руки, враждебное отношение, связанное с классовой борьбой, к казахам, имеющим несколько голов скота и т.д. сказалось на положении детей. О тяжелой обстановке, в которой оказалось подрастающее поколение, писалось следующее: «Условия жизни, в которых находятся большинство детей, не 
только не способствует воспитанию нового человека, но и губят в них с малых лет все человеческое. Очень много детей в настоящее время не только лишены семьи, влияния школы, но лишены самого необходимого - крова, пищи, одежды и влачат жалкое существование детей-улицы, занимаясь спекуляцией, воровством и проч. Очень часто можно встретить детей дошкольного и школьного возрастов, торгующих папиросами в казармах среди солдат; слоняющихся без цели по вокзалам и притонам» (Койгельдиев, 2007: 90). В тех условиях проводить мероприятия, направленные на улучшение просвещения, было непросто. Хотя большевистская партия пыталась вести борьбу с неграмотностью населения страны советов. В некоторой степени это ей удалось в начале $30-x$ годов XX века, когда принимались меры по введению всеобщего начального образования.

Тем не менее, образовательный уровень казахов был не на высоте. А.Байтурсунов в своем заявлении (Оренбург. 15 ноября 1921 г.), с протестом против исключения его из рядов РКП(б), одним из поводов которого стало участие в организации «Алаш-Орды», он, наряду со многими проблемами в казахском обществе, описывает положение в области культурного развития казахского народа: «Перед нами киргизский народ, умственно отсталый, чувственно погрязший в своем обычае, который хватает колеса прогресса за спицы всякий раз, когда они хотят катиться более или менее быстро. Народ этот не имеет не только литературы, но и учебников на своем языке, т.е. у него нет и того основного, без которого нельзя начать какой-либо культурно-просветительской работы. В принципе признано нужным вести среди киргизов политпросветительную, агитпропагандистскую, партийную и всякую иную работу, и существуют для этого ряд организаций и учреждений. Ведутся ли сказанные работы среди киргизов? Нет. Если взять самую простую работу вроде открытия библиотек, изб-читален, то и этой работы нельзя вести среди киргизов. Смешно говорить об открытии для киргизов библиотек и читален, не имея литературы на киргизском языке» (Койгельдиев 2007: 99). Для открывающихся школ советского Казахстана не было учебников на родном языке. Была поставлена задача перевести следующие учебники: арифметику, геометрию, географию, киргизскую историю, всеобщую историю, школьную гигиену, алгебру первоначальную, педагогику, дидактику. В этой работе приняли участие представители алашской интеллигенции: А. Букейханов, М. Жумабаев, Ж. Тлеулин и другие.

Ситуация в некоторой степени стала выправляться в ходе борьбы с неграмотностью. Шло повсеместное обучение детей и взрослых, функционировали школы-юрты, получившие начальное образование учили других. Однако, в кампанию за всеобщую грамотность включилась политическая направляющая, нарушившая течение за улучшение культурного развития казахского народа.

В конце 20-х годов 20 века в Казахстане развернулась дискуссия по вопросу перехода на латинскую графику. Ее противником выступил А. Байтурсынов, отстаивавший необходимость сохранения арабицы, мотивируя тем, что перемены в алфравитах приведет к нарушению преемственности и потери духовных ценностей казахского народа. За такой подход он подвергался сильнейшей критике со стороны коммунистов. В фреврале-марте 1932 года по этому поводу о нем писали следующее: «Большое вредительское сопротивление мы имели со стороны Байтурсынова при введении нового алфавита казахского языка. А. Байтурсынов был вождем противников нового алфавита. Влияние его настолько сильно, что он перетянул на свою сторону даже некоторую часть казахских коммунистов. Мало того, против этого всемирно-исторического революционно- 
го мероприятия, по выражению В.И. Ленина - «революция на Востоке», чего только не сочинял, не выдумывал Байтурсынов! Байтурсыновы всячески старались спровоцировать это движение за новый алфавит и распространяли по «узун-кулаку» всякие контрреволюционные провокационные хабары о новом алфавите» (Посланцы Ленина 1987: 130). Большевикам удалось провести свою линию в казахском алфавите. Латинизация по идее коммунистов должна вести к укреплению связей с мировым пролетариатом. Истинная причина отказа от арабской графрики заключалась в религиозной политике советского правительства среди мусульман, направленная на разрыв с исламом. Но затея о «контакте» с рабочими других стран на основе латинского алфавита оказался слишком краткосрочной. На повестке дня появилась более важная задача: объединение и сплочение двух братских народов: казахского и русского.

Против введения латинской графики выступал и М. Дулатов, считавший, что «вместо ликвидации неграмотности «мы получим еще больше безграмотных людей», к тому же нет достаточных средств. Он предлагал сохранить и совершенствовать тюркское письмо. Х. Досмухамедов отмечал, что еще не в полной мере изучены внутренние резервы казахского языка, и предлагал вводить новые термины постепенно, на основе общественного обсуждения» (Тугай 2017: 173).

Первый всеказахский староста С. Мендешев в 1930-1937 годах являлся наркомом просвещения. В эти годы «завершился переход от сложной арабской письменности к облегченному латинскому алфавиту, ставшему переходной ступенью к последующему введению нового алфавита, построенного на основе русской письменности, что способствовало укреплению дружбы и сотрудничества казахского и русского народов» (Посланцы Ленина 1987: 166). За небольшой промежуток времени с 1927 по 1940 годы казахи пережили кардинальные перемены в алфавите: от арабской к латинице, от нее к кириллице. Эти изменения отразились на состоянии образования. Учитывая сложные времена, недостаток в помещениях, учебниках, учительских кадрах, к которым прибавились трудности перехода в алфравитах, о достижениях в борьбе с неграмотностью докладывать было нелегко.

К сожалению, периодическое преследование бывших участников «АлашОрды», отразилось на их поступках. Многолетняя служба верой и правдой большевистской партии не помогла им избежать расправы. Тот же С. Мендешев, который «выступал против назначения на ответственные посты, особенно в правительство и ЦИК Казахстана, деятелей из верхушки буржуазнонационалистической партии «Алаш», алашордынских правительств и комитетов», о чем он открыто говорил «с трибуны съездов Советов, партийных конфреренций, пленумов обкома и крайкома партии» (Посланцы Ленина 1987: 163) тоже был репрессирован и расстрелян в 1938 году.

На благо просвещения своего народа трудился один из активных деятелей алашского движения Жумагали Тлеулин. В начале двадцатых годов остро стоял вопрос о подготовке учительских кадров. Предполагалось открыть краткосрочные курсы в каждом уезде и районе. Уже «в июне 1920 г. в городе Петропавловске были открыты краткосрочные курсы «Красных учителей», где заведующим был участник алашского движения Магжан Жумабаев» (Муканов 2005: 32). За сжатые три месяца сложно было дать необходимые знания будущим педагогам. Было принято решение открыть курсы, где обучение шло на протяжении трех лет. Позже в 1922 г. они были преобразованы в педтехникум с русским и казахским языком обучения. Казахским педтехникумом заведовал Жумагали Тлеулин и проводивший занятия по истории, анатомии и педагогике. 
Фельдшер по образованию, он сумел поставить работу в учебном заведении на такую высоту, что его выпускники продолжали дело первого директора в 4060-е годы. Ж.Тлеулин, не покладая рук работал на благо техникума: занимался набором учащихся, устройством их в общежитие, заботился о их питании, подбирал педагогов. Большое значение в те годы придавалось шефской работе. Принимали участие в ней и учащиеся казахского техникума, выезжавшие в подшефные аулы, а также проводили широкую работу в городе ${ }^{2}$.

Плодотворной работе на должности директора педагогического техникума порой мешало преследование за прошлое, а именно участие в алашском движении. Некоторые рьяные сторонники советской власти никак не могли смириться, с объявленной в 1919 году, амнистией алашординцев и подбирая удобный момент, устраивали на них новые нападки, наносили очередной удар. В апреле 1921 г. вышел документ, где разъяснялось, что на основании решений Революционного Военного Совета Туркфронта от 20 ноября 1920 г., ВЧК, позже КИРЦИКОМа и губревкома прекратить преследование бывших участников алашского движения ${ }^{3}$.

Но это обращение не остановило нападки на людей, причастных к «АлашОрде». В публикации Рибаса под названием ««Алаш-ординцам нет места в Советах» в газете «Мир труда» 9 августа 1922 г. основной акцент делается на фактах из жизни казахских эксплуататоров, использовании ими различных форм присвоения продуктов чужого труда. В завершении письма автор возвращается к событиям гражданской войны. Напоминает о «вождях киргизской интеллигенции, сынах и наймитах буржуев и кулаков, перечисляет фрамилии, среди которых стоит Ж. Тлеулин (Рибас 1922). Игнорируя указания Реввоенсовета, Чрезвычайной комиссии и Киргизского исполнительного комитета о прекращении преследований, автор старается поднять вопрос об «Алаш-Орде», делая упор на период противостояния идейных противников.

Ж. Тлеулин в открытом письме, отвечая на обвинения автора публикации, пишет, что в период «службы при Советской власти ими не проводилась агитация против нее, что могут подтвердить свидетели в лице ответственных работников тех учреждений, где ему проходилось служить» (Тлеулин 1922). В завершении Ж. Тлеулин рекомендует автору письма обратиться по данному вопросу в соответствующие органы. Ж. Тлеулину не простили причастность к алашскому движению: в 1938 году он был осужден трибуналом Туркестанского военного округа и приговорен к расстрелу.

Таким образом, изучение и анализ наследия алашской интеллигенции по проблеме образования в Казахстане дает возможность увидеть их вклад в дело просвещения детей. Они мечтали увидеть казахов образованными, культурными, идущими по пути прогресса вместе с мировым сообществом.

\section{Әдебиеттер тізімі/ Список литературы}

1. Ахметов Л.С. Алихан Букейханов - поиск ориентиров. Ахмет Байтурсунов - главное обретение независимости. Турар Рыскулов - яркий политик советского Востока. - Астана, 2008. 204 c.

2. Байтелесова Ж. Негасимая звезда в плеяде казахской интеллигенции (об А. Байтурсунове).

- А: Мектеп,1998. - 78 с.

3. Байтурсунов А. Сочинения (на каз.яз.). - Алма-Ата: Жазушы, 1989. - 320 с.

4. Бержанов К. Русско-казахское содружество в развитии просвещения (историкопедагогическое исследование). - Алма-Ата: Казахстан, 1965. - 344 с.

${ }^{2}$ Северо-Казахстанский областной архив. Ф.1074, оп.1, д.38, лл. 1-27

${ }^{3}$ СКОА. Ф. 55. Оп. 4. Д. 1. л. 132 
5. Букейханов А.Н. Казахи: историко-этнографические труды. 2-е изд.доп. - Т.14. - Астана: Алтын китап, 2007. - 303 с.

6. Букейханов А. Избранное. - Алма-Ата: Ғылым, 1993. - 478 с.

7. Галиев В.З. Книга, разбудившая народ (Разыскания о Мыржакыпе Дулатове и его сборник «Проснись, казах!»). - Алматы: Мектеп, 2011. - 528 с.

8. Дулатов М. Избранное. - Алма-Ата: Гылым, 1997. - 205 с.

9. Движение Алаш. Апрель 1920-1928 гг. / Составитель М. Койгельдиев. - Алматы: «Елшежире», 2007. - 304 с.

10. Кул-Мухаммед М. Жакып Акпаев. Патриот. Политик. Правовед. - Алматы: Атамура, 1995. $240 \mathrm{c}$.

11. Кыдыралина Ж.У. Алимхан Ермеков. - Астана: Фолиант, 2012. - 320 с.

12. Муканов К. Жумагали Тлеулин. Документальная биография. - Алматы: Издательский дом «Жибек жолы», 2005. - 216 с.

13. Муканов К. Мечта благородных людей. - Астана, 2014. - 294 с.

14. Материалы международной научно-практической конференции в честь 100-летия «АлашОрды» «Алаш-Орда»: воплощение идеи независимости Казахстана. - Алматы: Международный университет информационных технологий, 2017. - 421 с.

15. Мамания. Исторические источники, воспоминания, песни, документы, выступления. / Составитель Ж. Калиулы. - Алматы: Атамура, 1999. - 272 с.

16. Посланцы Ленина в Казахстане: Сб.очерков. - Алма-Ата: Казахстан, 1987. - 312 с.

17. Рибас. Алаш-ординцам нет места в Советах // Мир труда. - 1922. - 9 августа.

18. Решение учительского съезда. // Газета «Казах».

19. Сабитов Н. Мектебы и медресе у казахов. - Алма-Ата: АН КазССР, 1950. - 44 с

20. Сембаев А.И., Храпченков Г.М. Очерки истории школ Казахстана.1900-1917. - Алма-Ата: Мектеп, 1972. - 164 с.

21. Сейфуллин С. Избранное: стихотворения, поэмы, повести, рассказ. Пер. с казахского. М: Художественная литература, 1987 - 399 с.

22. Тажибаев Т. Просвещение и школы Казахстана во второй половине XIX века. - Алма-Ата: Казгосиздат политической литературы, 1962. - 507 с.

23. Тажибаев Т. Педагогическая мысль Казахстана во второй половине XIX века. - Алма-Ата: АН КазССР, 1965. - $164 \mathrm{c}$.

24. Юнг Т. Учителя эпохи сталинизма: власть, политика и жизнь школы 1930-х годов (пер.с англ. Д.А.Благова) - М.: Рос.полит.энциклоп. (РОССПЭН), 2011. - 359 с.

25. Тынышпаев М. История казахского народа. - Алма-Ата: Санат, 2009. - 279 с.

26. Тугай Т.И. Оренбургский путь Ахмета Байтурсунова. - Оренбург: ООО ИПК «Университет», 2017. $-188 \mathrm{c}$.

27. Тлеулин Ж. Открытое письмо// Мир труда. - 1922. - 13 августа.

\section{Reference}

Ahmetov 2008 - Ahmetov, LS 2008, Alihan Bukejhanov - poisk orientirov. Ahmet Baj-tursunov - glavnoe obretenie nezavisimosti. Turar Ryskulov - yarkij politik sovetskogo Vostoka, Astana, 204 p. (Ahmetov, LS 2008, Alikhan Bukeikhanov-search for landmarks. Ahmet Buy-Tursunov-important independence. Turar Ryskulov is a bright politician of the Soviet East., Astana, 204 p). (in Rus).

Bajtelesova 1998 - Bajtelesova, Zh 1998, Negasimaya zvezda v pleyade kazahskoj intelligencii (ob A. Bajtursunove), Mektep, Almaty, 78 s. (Bajtelesova, Zh 1998, The Eternal star in the galaxy of Kazakh intellectuals (A. Baitursunov), Mektep, Almaty, 78 p). (in Rus).

Bajtursunov 1989 - Bajtursunov, A 1989, Sochineniya, ZHazushy, Alma-Ata, 320 s. (Bajtursunov, A 1989, Sochineniya, ZHazushy, Alma-Ata, 320 p). (in Kaz).

Berzhanov 1965 - Berzhanov, K 1965, Russko-kazahskoe sodruzhestvo $v$ razvitii prosveshcheniya (isto-riko-pedagogicheskoe issledovanie), Kazahstan, Alma-Ata, 344 p. (Berzhanov, K 1965, Russian-Kazakh Commonwealth in the development of education (historical and pedagogical research), Kazahstan, Alma-Ata, 344 p). (in Rus).

Bukejhanov, 2007 - Bukejhanov, AN 2007, Kazahi: istoriko-ehtnograficheskie trudy. 2-e izd.dop, T.14, Altyn kitap, Astana, 303 s. (Bukejhanov, AN 2007, Kazakhs: historical and ethnographic works. 2e Ed, T.14, Altyn kitap, Astana, 303 p). (in Rus).

Bukejhanov 1993 - Bukejhanov, A 1993, Elected, Gylym, Alma-Ata, 478 p. (Bukejhanov, A 1993, Elected, Gylym, Alma-Ata, 478 p). (in Rus).

Galiev 2011 - Galiev, VZ 2011, Kniga, razbudivshaya narod (Razyskaniya o Myrzhakype Dulatove $i$ ego sbornik «Prosnis', kazah!»), Mektep, Almaty, 528 s. (Galiev, VZ 2011, Kniga, razbudivshaya narod (Razyskaniya o Myrzhakype Dulatove i ego sbornik «Prosnis', kazah!»), Mektep, Almaty, 528 p). (in Rus). 
Dulatov 1997 - Dulatov, M 1997, Izbrannoe, Gylym, Alma-Ata, 205 s. (Dulatov, M 1997, Izbrannoe, Gylym, Alma-Ata, 205 p). (in Rus).

Dvizhenie 2007 - Dvizhenie Alash. Aprel' 1920-1928 gg. 2007, Ed. M. Kojgel'diev, «El-shezhire», Almaty, 304 s. (Alash Movement. April 1920-1928 2007, Ed. M. Kojgel'diev, «El-shezhire», Almaty, 304 p). (in Rus).

Kul-Muhammed 1995 - Kul-Muhammed, M 1995, ZHakyp Akpaev. Patriot. Politik. Pravoved, Atamura, Almaty, 240 s. (Kul-Muhammed, M 1995, Zhakyp Akpaev. Patriot. Politician. Lawyer, Atamura, Almaty, 240 p). (in Rus).

Kydyralina 2012 - Kydyralina, ZhU 2012, Alimhan Ermekov, Foliant, Astana, 320 s. (Kydyralina, ZhU 2012, Alimhan Ermekov, Foliant, Astana, 320 p.). (in Rus).

Mukanov 2005 - Mukanov, K 2005, ZHumagali Tleulin. Dokumental'naya biografiya, Izda-tel'skij dom «ZHibek zholy», Almaty, 216 s. (Mukanov, K 2005, Zhumagali Tleulin. Documentary biography, Izda-tel'skij dom «ZHibek zholy», Almaty, 216 s). (in Rus).

Mukanov 2014 - Mukanov, K 2014, Mechta blagorodnyh lyudej, Astana, 294 s. (Mukanov, K 2014, The Dream of noble people, Astana, 294 s). (in Kaz).

Materialy 2017 - Materialy mezhdunarodnoj nauchno-prakticheskoj konferencii $v$ chest' 100-letiya «Alash-Ordy» «Alash-Orda»: voploshchenie idei nezavisimosti Kazahstana. Alma-ty: Mezhdunarodnyj universitet informacionnyh tekhnologij 2017, $421 \mathrm{~s}$. (Materials of the international scientific and practical conference in honor of the 100th anniversary of "Alash-Orda": the embodiment of the idea of independence of Kazakhstan 2017, 421 p). (in Rus).

Mamaniya 1999 - Mamaniya. Istoricheskie istochniki, vospominaniya, pesni, dokumenty, vystupleniya 1999, Sostavitel Zh.Kaliuly, Atamura, Almaty, 272 p. (Mamania. Historical sources, memoirs, songs, documents, you offenses 1999, Ed. Zh.Kaliuly, Atamura, Almaty, 272 p). (in Rus).

Poslancy 1987 - Poslancy Lenina v Kazahstane: Sb.ocherkov 1987, Kazahstan, Alma-Ata, 312 p. (Lenin's Envoys to Kazakhstan: Sat.essays 1987, Kazahstan, Alma-Ata, 312 p). (in Rus).

Ribas 1922 - Ribas 1922, Alash-ordincam net mesta v Sovetah, Mir truda, 9 avgusta. (Ribas 1922, Alash-residents have no place in the Soviets, World of labour, August 9). (in Rus).

Sabitov 1950 - Sabitov, N 1950, Mekteby i medrese u kazahov, AN KazSSR, Alma-Ata, 44 s. (Sabitov, N 1950, The mektebs and madrasahs of the Kazakhs, AN KazSSR, Alma-Ata, $44 \mathrm{~s}$ ). (in Rus).

Sembaev, Hrapchenkov 1972 - Sembaev, Al, Hrapchenkov, GM 1972, Ocherki istorii shkol Kazahstana.1900-1917, Mektep, Alma-Ata, 164 p. (Sembaev, Al, Hrapchenkov, GM 1972, Essays on the history of the schools of Kazakhstan.1900-1917, Mektep, Alma-Ata, 164 p). (in Rus).

Sejfullin 1987 - Sejfullin, S 1987, Izbrannoe: stihotvoreniya, poehmy, povesti, rasskaz, Hudozhestvennaya literatura, 399 s. (Sejfullin, S 1987, Favorites: verses, poems, stories, story, Hudozhestvennaya literatura, $399 \mathrm{~s}$ ). (in Rus).

Tazhibaev 1962 - Tazhibaev, T 1962, Prosveshchenie i shkoly Kazahstana vo vtoroj polovine XIX veka, Kazgosizdat politicheskoj literatury, Alma-Ata, 507 s. (Tazhibaev, T 1962, Education and schools of Kazakhstan in the second half of the XIX century, Kazgosizdat politicheskoj literatury, Alma-Ata, 507 s). (in Rus).

Tazhibaev 1965 - Tazhibaev, T 1965, Pedagogicheskaya mysl' Kazahstana vo vtoroj polovine XIX veka, AN KazSSR, Alma-Ata, 164 s. (Tazhibaev, T 1965, Pedagogical thought of Kazakhstan in the second half of the XIX century, AN KazSSR, Alma-Ata, $164 \mathrm{~s}$ ). (in Rus).

Tomas YUng 2011 - Tomas Yung 2011, Uchitelya ehpohi stalinizma: vlast', politika i zhizn' shkoly 1930-h godov (per.s angl. D.A.Blagova), Ros.polit.ehnciklop. (ROSSPEHN), Moscow, 359 p. (Tomas Yung 2011, Teachers of the era of Stalinism: power, politics and school life of the 1930s (per.s angl. D.A.Blagova), Ros.polit.ehnciklop. (ROSSPEHN), Moscow, 359 p). (in Rus).

Tynyshpaev 2009 - Tynyshpaev, M 2009, Istoriya kazahskogo naroda, Sanat, Alma-Ata, 279 s. (Tynyshpaev, M 2009, History of the Kazakh people, Sanat, Alma-Ata, 279 s). (in Rus).

Tugaj 2017 - Tugaj, TI 2017, Orenburgskij put' Ahmeta Bajtursunova, OOO IPK «Uni-versitet», Orenburg, 188 p. (Tugaj, TI 2017, Orenburg way of Akhmet Baitursunov, OOO IPK «Universitet», Orenburg, 188 p). (in Rus).

Tleulin 1922 - Tleulin, Zh 1922, Otkrytoe pis'mo, Mir truda, 13 avgusta. (Tleulin, Zh 1922, Open letter, World of labour, August of 13). (in Rus). 